\title{
PENAMBAHAN VITAMIN C PADA PAKAN BUATAN TERHADAP PERTUMBUHAN BENIH IKAN GABUS (Channa striata)
}

\author{
Tisie Hawa Alfisha, M. Bahrus Syakirin, Tri Yusufi Mardiana, Linayati, Benny Diah Madusari \\ Program Studi Budidaya Perairan, Fakultas Perikanan Universitas Pekalongan \\ Korespondensi : yusufihanum@yahoo.co.id
}

\begin{abstract}
The purpose of this study was to determine the effect of adding vitamin $C$ in artificial feed and the optimum dose to the growth of snakehead fish seeds. The research method used was a completely randomized design with 4 treatments and 3 replications. The treatments used were: A (giving vitamin $C$ at a dose of $50 \mathrm{mg} / \mathrm{kg}$ of feed), B (giving vitamin C at a dose of $100 \mathrm{mg} / \mathrm{kg}$ of feed), C (giving vitamin C at a dose of $150 \mathrm{mg} / \mathrm{kg}$ of feed), D ( giving vitamin C at a dose of $200 \mathrm{mg} / \mathrm{kg}$ of feed). The results showed that the highest average biomass growth was obtained in treatment $D$ with a dose of vitamin C $200 \mathrm{mg} / \mathrm{kg}$ of feed, the increase in biomass reached 3.04 grams. While the lowest growth was obtained in treatment A with a dose of vitamin C $50 \mathrm{mg} / \mathrm{kg}$ of feed resulting in an average growth of 1.09 grams. The results of the analysis of variance on the growth of snakehead fish seed biomass showed that the calculated $F$ value was greater than $F$ table $1 \%$ and $5 \%$. The range of water temperature during the study was between $27-30^{\circ} \mathrm{C}$, water $\mathrm{pH}$ ranged from 7.4-7.6 and dissolved oxygen in water $(D O)$ ranged from 4.2-4.9 $\mathrm{mg} / \mathrm{l}$.
\end{abstract}

Keywords: snakehead, vitamin $C$, growth

\section{PENDAHULUAN}

Ikan gabus (Chana striata) juga sering disebut snakehead fish merupakan jenis ikan ekonomis penting di perairan umum dan potensial untuk dikembangkan. Ikan gabus merupakan jenis ikan air tawar yang banyak dijumpai di perairan umum. Habitat ikan gabus adalah di muara sungai, danau, rawa, bahkan dapat hidup di perairan yang kandungan oksigennya rendah. Dalam dunia kedokteran, ikan gabus dikenal manfaatnya dapat mempercepat proses penyembuhan luka pasca operasi. Hal ini dikarenakan tingginya kandungan albumin pada ikan gabus. Di sisi lain, ikan gabus banyak dimanfaatkan sebagai bahan makanan (Yulisman dkk., 2012).

Untuk memenuhi permintaan ikan gabus yang semakin meningkat, maka intensitas penangkapan ikan gabus di alam juga semakin meningkat. Semakin intensifnya penangkapan ikan gabus memberikan dampak terhadap menurunnya populasi ikan gabus di alam (Muslim, 2007). Pada sistem budidaya dengan intensifikasi yang tinggi, salah satu permasalahan yang sering dihadapi adalah mortalitas. Mortalitas dapat diakibatkan oleh stres pada ikan karena kondisi lingkungan dan kepadatan yang tinggi sehingga menyebabkan proses pertumbuhan terganggu. Ikan gabus, seperti halnya dengan ikan lainnya, memerlukan asupan nutrisi tertentu untuk memenuhi kebutuhannya seperti protein, lemak, karbohidrat, vitamin dan mineral. Nutrisi tersebut dibutuhkan untuk menghasilkan energi dan mengganti sel-sel yang rusak untuk pertumbuhan, untuk mendukung proses pertumbuhan pada ikan diperlukan peningkatan kualitas pakan dengan penambahan vitamin $\mathrm{C}$ dalam jumlah yang tepat (Heri $d k k ., 2002)$.

Vitamin mempunyai peranan sangat besar dalam proses fisiologis ikan. Salah satu vitamin yang mempunyai peran yang sangat penting dalam proses fisiologis ikan yaitu vitamin $\mathrm{C}$. Vitamin $\mathrm{C}$ merupakan nutrien yang keberadaannya dalam jumlah mikro di dalam pakan, tetapi harus tersedia. Walaupun dibutuhkan dalam jumlah yang sedikit, vitamin $\mathrm{C}$ harus didapatkan dari pakan, karena tubuh tidak dapat membuatnya sendiri (Jusadi dan Mokoginta, 2006). Menurut Lovell (1989), ikan mempunyai susunan yang terbatas 
untuk mensintesis vitamin $\mathrm{C}$ dan bergantung pada susunan pakan, sehingga ikan memerlukan asupan vitamin $\mathrm{C}$ dalam campuran pakan untuk meningkatkan pertumbuhan dan mengurangi stres, sesuai dengan pendapat Sukmawati (1999), vitamin C dapat digunakan untuk perlindungan dari serangan penyakit.

Penelitian penambahan vitamin $\mathrm{C}$ sudah dilakukan pada ikan lele (Clarias gariepenus) (Gbadamosi et al., 2013), ikan patin (Pangasius hypothalamus) (Jusadi \& Mokoginta, 2006), ikan betok (Anabas testudenueus) (Sunarto dkk., 2008), ikan mas (Cyprinus carpio) (Faramarzi, 2012), dan ikan nila gesit (Oreochromis sp) (Kursistiyanto $d k k ., 2013$ ). Kandungan vitamin pada pakan komersil sebesar 4\%, sedangkan kebutuhan vitamin C ikan sebesar 50-100 mg/kg (Halver, 1972). Menurut Aslianti dan Priyono (2009), kebutuhan ikan terhadap vitamin $\mathrm{C}$ untuk pertumbuhan yang optimum sangat bervariasi bergantung kepada spesies, umur, dan ukuran ikan. Tujuan penelitian untuk mengetahui pengaruh penambahan vitamin $\mathrm{C}$ pada pakan buatan terhadap pertumbuhan benih ikan gabus dan mengetahui dosis penambahan vitamin $\mathrm{C}$ yang optimum pada pakan buatan terhadap pertumbuhan benih ikan gabus.

\section{TINJAUAN PUSTAKA}

Vitamin $\mathrm{C}$ merupakan nutrien yang sangat dibutuhkan oleh tubuh. Vitamin $\mathrm{C}$ mempunyai peran yaitu untuk meningkatkan pertumbuhan normal, mencegah kelainan bentuk tulang, untuk kesehatan benih atau menguangi stres, mempercepat penyembuhan luka dan meningkatkan pertahanan atau kekebalan tubuh. Vitamin $\mathrm{C}$ termasuk golongan antioksidan karena sangat mudah teroksidasi oleh panas, cahaya, dan logam, oleh karena itu penggunaan vitamin $\mathrm{C}$ sangat sering dijumpai. Vitamin $\mathrm{C}$ juga dapat berperan sebagai imunostimulan yaitu merupakan sekelompok senyawa biologi dan sintetis yang dapat meningkatkan kekebalan tubuh (Johnny $d k k .$, 2007).

Vitamin $\mathrm{C}$ berfungsi sebagai penunjang dalam pertumbuhan, mengurangi tingkat stress serta dapat mempercepat penyembuhan luka pada ikan. Menurut Helver (1989) kekurangan vitamin C pada ikan dapat menyebabkan kerusakan pada insang dan rendahnya tingkat pertumbuhan serta kelangsungan hidup ikan. Vitamin $\mathrm{C}$ juga berfungsi sebagai pembentuk jaringan kolagen. Menurut Masumoto et al., (1991), bahwa kolagen merupakan komponen pembentuk tulang pada ikan yang diserap secara cepat pada kulit, sirip punggung, kepala, insang, tulang rawan, rahang, tulang rawan penunjang dan mulut. Maka dari itu kebutuhan vitamin C pada ikan mutlak diperlukan.

Menurut Lovell (1989), bahwa kebutuhan vitamin $\mathrm{C}$ berbeda pada setiap hewan tergantung pada spesies, umur, ukuran ikan, laju pertumbuhan, lingkungan dan fungsi metabolismenya. Menurut Halver (1972), kebutuhan vitamin C ikan berkisar 50-100 $\mathrm{mg} / \mathrm{kg}$, sedangkan kandungan vitamin yang ada pada pakan komersil hanya $4 \%$, sehingga perlu penambahan vitamin $\mathrm{C}$ pada pakan. Menurut Dewantara dan Melissa (2008), bahwa pemberian vitamin C $100 \mathrm{mg} / \mathrm{kg}$ dalam pakan ikan patin (Pangasius hypophthalmus) dapat meningkatkan pertumbuhan.

\section{METODE PENELITIAN}

Penelitian dilaksanakan pada tanggal 23 September - 23 Oktober 2020 bertempat di Laboratorium Air Payau dan Laut Fakultas Perikanan Universitas Pekalongan. Alat-alat yang digunakan dalam penelitian ini meliputi toples, timbangan digital, gelas ukur, sprayer, DO meter, pH meter, termometer, scopnet, alat tulis, kamera dan selang. Sedangkan bahanbahan yang digunakan dalam penelitian ini yaitu ikan gabus ukuran 6-8 cm, pakan komersil, dan vitamin C.

Penelitian menggunakan Rancangan Acak Lengkap (RAL) dengan empat perlakuan dan tiga kali ulangan. Adapun dosis perlakuan yang digunakan yaitu:

$$
\begin{aligned}
& \text { A = Pakan + Vitamin C } 50 \mathrm{mg} / \mathrm{kg} \\
& \text { B = Pakan + Vitamin C } 100 \mathrm{mg} / \mathrm{kg} \\
& \text { C = Pakan + Vitamin C } 150 \mathrm{mg} / \mathrm{kg} \\
& \text { D = Pakan + Vitamin C } 200 \mathrm{mg} / \mathrm{kg} \\
& \text { Penentuan dosis pada penelitian ini }
\end{aligned}
$$
merujuk pada Jusadi dan Mokoginta (2006), tentang pengaruh penambahan vitamin $\mathrm{C}$ pada pakan buatan terhadap pertumbuhan ikan patin. Hasil percobaan pertumbuhan benih ikan patin 
dengan penambahan vitamin $\mathrm{C}$, menghasilkan pertumbuhan tertinggi dengan dosis $100 \mathrm{mg} / \mathrm{kg}$ pakan.

\subsection{Persiapan Wadah dan Ikan}

Wadah yang digunakan adalah toples dengan volume $10 \mathrm{~L}$. Sebelum digunakan toples tersebut dicuci terlebih dahulu, lalu dibilas hingga bersih. Setelah bersih toples diisi air sebanyak $5 \mathrm{~L}$ dan masing-masing toples diisi 5 ekor.

\subsection{Persiapan Pakan Uji}

Pencampuran vitamin $\mathrm{C}$ dalam pakan uji dilakukan dengan cara melarutkan vitamin $\mathrm{C}$ pada setiap perlakuan kedalam $30 \mathrm{ml}$ air, kemudian dimasukkan ke dalam botol semprotan sesuai dosis yang telah ditentukan. Larutan vitamin $\mathrm{C}$ disemprotkan pada pakan uji dan diaduk hingga merata. Pakan uji selanjutnya dikeringkan dengan cara dianginanginkan selama 30 menit, setelah kering pakan uji yang telah disemprot vitamin $\mathrm{C}$ selanjutnya dimasukkan ke dalam toples dan disimpan pada suhu ruangan.

\subsection{Pemeliharaan}

Ikan gabus dipelihara selama 30 hari. Pemberian pakan dilakukan secara at satiation (sekenyangnya). Frekuensi pemberian pakan dilakukan tiga kali sehari, yaitu: pada jam 08.00, 12.00 dan 16.00 WIB. Pemberian pakan dilakukan sebanyak 5\% dari biomassa (Hidayat $d k k ., 2013)$

\subsection{Parameter Penelitian}

\subsubsection{Pertumbuhan Biomassa}

Rumus yang digunakan untuk menghitung pertumbuhan biomassa menurut Effendie (1979) adalah :

$$
\mathbf{W}=\mathbf{W t}-\mathbf{W o}
$$

Keterangan :

W : Pertumbuhan bobot mutlak (g)

Wt : Bobot ikan akhir (g)

Wo : Bobot ikan awal (g)

\subsubsection{Kelangsungan Hidup (Survival Rate)}

Tingkat kelangsungan hidup dihitung dengan menggunakan rumus Goddard (1996), sebagai berikut :

$$
\mathrm{SR}=\frac{\mathrm{Nt}}{\mathrm{No}} \times 100 \%
$$

Keterangan :

SR : Survival Rate (\%)

$\mathrm{Nt}$ : Jumlah ikan hidup di akhir pemeliharaan (ekor)

No : Jumlah ikan pada awal pemeliharaan (ekor)

\subsubsection{Kualitas Air}

Parameter kualitas air yang diukur selama penelitian yaitu: suhu, $\mathrm{pH}$, dan DO. Suhu diukur menggunakan termometer, $\mathrm{pH}$ diukur dengan menggunakan $\mathrm{pH}$ meter, dan $\mathrm{DO}$ diukur menggunakan DO meter.

\subsection{Analisis Data}

Untuk menguji hipotesis data tersebut di atas menggunakan analisis ragam. Sebelum dilakukan analis data, terlebih dahulu dilakukan pra analisa yang meliputi uji normalitas dan uji homogenitas. Uji normalitas dilakukan menggunakan uji Liliefors (Nasoetion dan Barizi, 1983) untuk mengetahui apakah data terdistribusi secara normal atau tidak, dan uji homogenitas ragam digunakan uji Bartlett (Sudjana, 1996) untuk mengetahui apakah ragam data yang dianalisis homogen atau justru sebaliknya. Kemudian dilakukan analisis ragam (ANOVA) dan uji tukey untuk mengetahui perbedaan pada tiap perlakuan

\section{HASIL DAN PEMBAHASAN 4.1. Hasil}

\subsubsection{Pertumbuhan Biomassa Ikan Gabus}

Data pertumbuhan rata-rata ikan gabus yang dipelihara selama penelitian disajikan pada Tabel 1.

Tabel 1 Pertumbuhan rata-rata ikan gabus selama pemeliharaan

\begin{tabular}{clllll}
\hline \multirow{2}{*}{ Ulangan } & \multicolumn{4}{c}{ Perlakuan } & Total \\
\cline { 2 - 6 } & $\mathrm{A}$ & $\mathrm{B}$ & $\mathrm{C}$ & $\mathrm{D}$ & \\
\hline 1 & 0.94 & 1.65 & 2.07 & 2.94 & \\
2 & 1.2 & 1.55 & 2.01 & 3.3 & \\
3 & 1.13 & 1.37 & 2.14 & 2.87 & \\
\hline Jumlah & 3.27 & 4.57 & 6.22 & 9.11 & 23.17 \\
Rerata & 1.09 & 1.52 & 2.07 & 3.04 & \\
\hline
\end{tabular}

Berdasarkan tabel 1, dapat dilihat pertumbuhan biomassa benih ikan gabus yang memiliki nilai tertinggi adalah pada perlakuan D dengan nilai rerata yaitu sebesar $3.04 \mathrm{~g}$, sedangkan pertumbuhan biomassa benih ikan gabus yang memiliki nilai terendah diperoleh pada perlakuan A dengan nilai rerata sebesar $1.09 \mathrm{~g}$.

Hasil uji normalitas yang didapatkan dari rata-rata pertumbuhan biomassa mutlak selama penelitian 30 hari menunjukkan bahwa data tersebar normal kemudian dilanjutkan dengan uji homogenitas dan menghasilkan data yang 
bersifat homogen maka data tersebut dapat dianalisis ragam (ANOVA). Berdasarkan analisis ragam $\mathrm{F}$ hitung $88.4527>\mathrm{F}$ tabel $1 \%$ yaitu 7.59. Hal inilah yang dapat menunjukkan bahwa adanya perbedaan pengaruh yang sangat nyata antar perlakuan.

\subsubsection{Kelangsungan Hidup}

Kelangsungan hidup selama penelitian tersaji pada Tabel 2.

Tabel 2 Kelangsungan hidup

\begin{tabular}{ccccc}
\hline \multirow{2}{*}{ Ulangan } & \multicolumn{4}{c}{ Perlakuan } \\
\cline { 2 - 5 } & $\mathrm{A}$ & $\mathrm{B}$ & $\mathrm{C}$ & $\mathrm{D}$ \\
\hline 1 & 5 & 5 & 5 & 5 \\
2 & 5 & 5 & 5 & 5 \\
3 & 5 & 5 & 5 & 5 \\
\hline Jumlah & 15 & 15 & 15 & 15 \\
\hline SR $(\%)$ & 100 & 100 & 100 & 100 \\
\hline
\end{tabular}

\subsubsection{Kualitas Air}

Kualitas air selama penelitian tersaji pada Tabel 3 berikut ini.

Tabel 3 Parameter Kualitas Air

\begin{tabular}{cccc}
\hline Parameter & $\begin{array}{c}\text { Nilai } \\
\text { Kualitas } \\
\text { Air }\end{array}$ & $\begin{array}{c}\text { Nilai } \\
\text { Optimal }\end{array}$ & Pustaka \\
\hline Suhu $\left({ }^{0} \mathrm{C}\right)$ & $27-30$ & $25-33$ & Kordi, 2010 \\
DO $(\mathrm{mg} / \mathrm{L})$ & $4.2-4.9$ & $3-6$ & Kordi, 2010 \\
pH & $7.4-7.6$ & $6.5-8.5$ & Kordi, 2010 \\
\hline
\end{tabular}

\subsection{Pembahasan}

Hasil penelitian yang telah dilaksanakan diketahui bahwa pertumbuhan biomassa benih ikan gabus tertinggi terjadi pada perlakuan D yaitu dengan pemberian dosis vitamin $C$ sebesar $200 \mathrm{mg} / \mathrm{kg}$ pakan dengan pertumbuhan biomassa yang memiliki nilai rerata sebesar 3.04 gr, sedangkan pertumbuhan biomassa benih ikan gabus terendah terjadi pada perlakuan A yaitu pemberian dosis vitamin $\mathrm{C}$ sebesar $50 \mathrm{mg} / \mathrm{kg}$ pakan dengan pertumbuhan biomassa yang memiliki nilai rerata sebesar 1.09 gr.

Hasil uji normalitas varian yang didapatkan yaitu L Max $(0.143)<$ dari pada L tabel $1 \%$ (0.275), maka data pertumbuhan biomassa ikan gabus memiliki varian yang sama (equal variance) atau bisa dikatakan normal, selanjutnya dari hasil uji homogenitas varian yang sama pada uji normalitas terhadap pertumbuhan biomassa ikan gabus diketahui bahwa $\mathrm{X}^{2}$ hitung $(2.767)<$ dari pada $\mathrm{X}^{2}$ tabel
$1 \%$ (7.81) maka data bersifat homogen. Berdasarkan hasil analisis ragam diperoleh bahwa F hitung $88.4527>\mathrm{F}$ tabel $1 \%$ (4.07). Hal tersebut menunjukkan bahwa perlakuan yang dilakukan memiliki pengaruh perbedaan yang sangat nyata.

Pertumbuhan ikan gabus yang diberi penambahan vitamin $\mathrm{C}$ pada perlakuan $\mathrm{A}$ dengan dosis $50 \mathrm{mg} / \mathrm{kg}$ pakan, perlakuan B dengan dosis $100 \mathrm{mg} / \mathrm{kg}$ pakan, perlakuan $\mathrm{C}$ dengan dosis $150 \mathrm{mg} / \mathrm{kg}$ pakan, dan perlakuan D dengan dosis $200 \mathrm{mg} / \mathrm{kg}$ pakan yang memberikan pengaruh tertinggi yaitu pada perlakuan D. Hal ini sesuai dengan pendapat Narra et al (2015), bahwa pemberian vitamin C sebanyak $200 \mathrm{mg} / \mathrm{kg}$ dalam pakan ikan lele dapat membantu proses detoksifikasi ataupun mampu mencegah peroksidasi sel sehingga ikan mampu mengendalikan stres akibat lingkungan

Menurut Muslim dan Syaifudin (2012), bahwa pertumbuhan ikan gabus masih tergolong rendah dibandingkan dengan pertumbuhan ikan budidaya lainnya. Adapun kendala dalam budidaya ikan gabus yaitu belum tersedianya pakan yang memenuhi kebutuhan pertumbuhan ikan gabus dan rentannya benih terserang penyakit. Oleh karena itu, penambahan immunostimulan yang mampu mendukung kesehatan dan pertumbuhan ikan perlu dilakukan. Dalam penelitian ini ditemukan bahwa penambahan vitamin $\mathrm{C}$ sebanyak $200 \mathrm{mg} / \mathrm{kg}$ pakan ikan selama empat minggu ternyata dapat memacu pertumbuhan ikan. Hasil yang sama dilaporkan oleh Farida dkk (2014) benih ikan biawan (Helostoma temmincki) yang diberi vitamin C $200 \mathrm{mg} / \mathrm{kg}$ pakan menghasilkan peningkatan pertumbuhan secara signifikan dibandingkan dengan laju pertumbuhan ikan yang tidak diberi perlakuan vitamin $\mathrm{C}$ (kontrol). Penggunaan vitamin $\mathrm{C}$ dalam budidaya ikan memiliki potensi untuk memacu pertumbuhan ikan. Ikan yang diberi perlakuan ini memiliki berat tubuh lebih besar.

Menurut Syatriani dan Astrina (2010), salah satu fungsi vitamin $\mathrm{C}$ adalah absorpsi dan metabolisme besi. Vitamin $\mathrm{C}$ mereduksi besi feri menjadi fero dalam usus halus sehingga mudah diabsorpsi untuk meningkatkan petumbuhan. Menurut Pakaya (2014), vitamin C diabsorpsi melalui saluran cerna, pada bagian 
atas usus halus secara difusi lalu masuk ke peredaran darah melalui vena porta. Vitamin $\mathrm{C}$ terdistribusi luas dalam jaringan tubuh.

Vitamin dan mineral yang ada dalam pakan memiliki peran untuk meningkatkan pertumbuhan dan kesehatan ikan. Salah satu vitamin yang bekerja untuk keduanya adalah vitamin C. Penambahan vitamin C secara signifikan meningkatkan pertumbuhan, imunitas non spesifik dan mampu memproteksi ikan dari serangan patogen (Zhou et al., 2012). Kebutuhan vitamin $\mathrm{C}$ pada spesies akuatik sangat berbeda satu dengan lainnya tergantung jenis, ukuran dan makanan. Pemberian vitamin $\mathrm{C}$ menjadi sangat penting untuk ikan karena dapat menghasilkan pertumbuhan optimal, efisiensi pakan yang baik dan membantu fungsi fisologi dari organ. Selain itu, vitamin C berperan penting pada proses osmoregulasi, proteksi terhadap patogen dan antioksidatif agen (Dawood dan Koshio, 2016).

Kelangsungan hidup benih ikan gabus pada setiap perlakuan selama 30 hari penelitian ikan tidak mengalami mortalitas, dikarenakan ketersediaan makanan dalam penelitiaan ini cukup untuk memenuhi kebutuhan benih ikan gabus dalam mempertahankan diri. Menurut Yulianto (2006), kelangsungan hidup dipengaruhi oleh faktor dalam dan faktor luar, di mana faktor dari dalam merupakan faktor dari individu ikan tersebut dan faktor dari luar merupakan faktor yang dipengaruhi oleh kualitas pakan dan kualitas air. Ketersediaan makanan juga diduga cukup untuk memenuhi kebutuhan ikan gabus dalam mempertahankan diri, sedangkan untuk kualitas air media budidaya masih dalam kisaran kelayakan. Menurut Jusadi dan Mokoginta (2006), bahwa vitamin $\mathrm{C}$ berperan penting dalam menormalkan fungsi kekebalan tubuh dan mengurangi stres.

Hasil pengukuran suhu selama penelitian berkisar antara $27-30^{\circ} \mathrm{C}$. Hal ini sesuai dengan pendapat Kordi (2010), bahwa suhu air untuk menunjang perkembangan hidup ikan gabus berkisar antara $25-33^{\circ} \mathrm{C}$. Menurut Daelami (2002), semua jenis ikan mempunyai toleransi berbeda-beda terhadap suhu. Perubahan suhu dapat mengakibatkan stres pada ikan, nafsu ikan menurun, mudah terserang penyakit bahkan kematian mendadak.

Kisaran $\mathrm{pH}$ selama penelitian berkisar antara 7.4 - 7.6. Nilai $\mathrm{pH}$ tersebut masih dalam kisaran toleransi untuk menunjang kehidupan ikan gabus. Menurut Kordi (2010), kisaran nilai $\mathrm{pH}$ untuk pemeliharaan ikan gabus adalah 6.58.5 .

Kandungan oksigen terlarut selama penelitian, berada pada kisaran 4.2-5.5 mg/l. Menurut Kordi (2010), kisaran optimal kandungan oksigen untuk pemeliharaan ikan gabus adalah 3-6 mg/l. Ikan gabus mampu hidup di perairan yang minim oksigen karena mampu mengambil oksigen langsung dari udara dengan alat pernafasan tambahan.

\section{KESIMPULAN DAN SARAN}

Berdasarkan hasil penelitian yang telah dilaksanakan dapat disimpulkan bahwa:

a) Pemberian vitamin $\mathrm{C}$ berpengaruh sangat nyata terhadap pertumbuhan ikan gabus.

b) Pertumbuhan benih ikan gabus yang tertinggi yaitu pada perlakuan D sebanyak $200 \mathrm{mg} / \mathrm{kg}$ pakan yang dapat lakuan D dengan pemberian dosis vitamin menghasilkan pertumbuhan benih $3.04 \mathrm{~g}$.

Saran yang dapat diberikan yaitu, diperlukan penelitian lebih lanjut mengenai dosis vitamin $\mathrm{C}$ yang optimal karena pada pemberian vitamin $\mathrm{C}$ dengan dosis $200 \mathrm{mg} / \mathrm{kg}$ pakan, laju pertumbuhan masih terus meningkat.

\section{DAFTAR PUSTAKA}

Aslianti, T., dan Priyono, A. 2009. Peningkatan Vitalitas dan Kelangsungan Hidup Benih Kerapu Lumpur (Epinephelus coioides) Melalui Pakan yang Diperkaya dengan Vitamin C dan Kalsium. Jurnal Ilmu Kelautan dan Perikanan, 19(1). pp: 74-81.

Daelami. 2002. Agar Ikan Sehat. Jakarta: Penebar Swadaya.

Dawood, M.A.O. \& Koshio, S. 2016. Vitamin C supplementation to optimize growth, health and stress resistance in aquatic animals. Rev. Aquacult. 1-17.

Dewantara, B. A., dan Melissa, S. 2008. Pengaruh Kadar L-Ascorbyl-2- Phosphate Magnesium Yang Berbeda Sebagai 
Sumber Vitamin C Dalam Pakan Terhadap Pertumbuhan Ikan Patin (Pangasius hypophthalmus). Journal of Agroscience Fakultas Pertanian Universitas Suryakancana, 1(1). pp: 70-77.

Effendie, M., I. 1979. Biologi Perikanan. Yogyakarta: Yayasan Pustaka Nusatama.

Faramarzi, M. 2012. Effect of Dietary Vitamin $\mathrm{C}$ on Growth and Feeding Parameters, Carcass Composition and Survival Rate of Common Carp (Cyprinus carpio). Global Veterinaria, 8 (5). pp: 507-510.

Farida, H. Hasan, \& Dayanti. F. 2014. Pengaruh Vitamin C Dalam Pakan Terhadap Pertumbuhan Dan Sintasan Benih Ikan Biawan (Helostoma temmincki). Jurnal Ruaya Fakultas Perikanan dan Ilmu Kelautan Universitas Muhammadiyah Pontianak. 3 (1). pp: 41-47.

Gbadamosi, O.K., Fasakin, E.A, Adebayo, O.T., 2013. Clinical changes observed in Clarias gariepinus (Burchell 1822) fed varying levels of ascorbic acid supplementation. Afr. J. Agric. Res, 8(30), 4122-4127.

Gorddard, S. 1996. Feed Management In Intensive Aquaculture. New York: Chapman and Hall.

Halver, J. E. 1972. Fish Nutrition. Washington DC: National Academy of Science.

Heri, S., Jusadi, D. dan Mokoginta. I, 2002. Pengaruh L- Askorbil-2-Fosfat Magnesium terhadap Kemampuan Tubuh Mengatasi Stres dan Pertumbuhan Ikan Baung (Mystus nemurus). Hayati, 9(4). pp: 125129.

Helver, B. 1989. Comercil Fish Farming : Whit Special Referance to Fish Culture In Israel. NewYork: John Wiley adınd Sons.

Hidayat D, Sasanti A. D, dan Yulisman. 2013, Kelangsungan Hidup, Pertumbuhan dan Efisiensi Pakan Ikan Gabus (Channa striata) yang Diberi Pakan Berbahan Baku Tepung Keong Mas, Jurnal Akuakultur Rawa Indonesia, 1(2). pp: 85-94.

Johnny F, Mahardika K, Giri Ina dan Roza D. 2007. Penambahan Vitamin C Dalam Pakan Untuk Meningkatkan Imunitas Benih Ikan Kerapu Macan, Epinephelus Fuscoguttatus Terhadap Infeksi Viral
Nervous Necrosis. Jurnal Akuakultur Indonesia, 6(1). pp: 43-53.

Jusadi, B. A dan Mokoginta. I. 2006. Pengaruh Kadar L-Ascorbyl-2- Phosphate Magnesium Yang Berbeda Sebagai Sumber Vitamin C Dalam Pakan Terhadap Pertumbuhan Ikan Patin (Pangasius hypothalamus), Jurnal Akuakultur Indonesia Fakultas Perikanan dan Ilmu Kelautan Institut Pertanian Bogor, 5(1). pp: 21-29.

Kordi, K. M. 2010. Budidaya Biota Akuatik untuk Pangan, Kosmetik, dan Obat-obatan. Yogyakarta: Lily Publisher.

Kursistiyanto, N., Anggoro. S., dan Suminto. 2013. Penambahan Vitamin C pada Pakan dan Pengaruhnya Terhadap Respon Osmotik, Efisiensi Pakan dan Pertumbuhan Ikan Nila Gesit (Oreochromis sp.) Pada Media Dengan Osmolaritas Berbeda. Jurnal Saintek Perikanan Fakultas Ilmu Perikanan dan Kelautan Universitas Diponegoro, 8 (2): 66-75.

Lovell, T. 1989. Nutrition and Feed of Fish. New York: Book van Nostrand reinhold.

Masumuto, T. Hosokawa, H. and Shimeno ,S. 1991. Ascorbic Acids Role in Aquaculture Nutrition dalam Akiyama, D.M. and Tan, R.K.H. (ed). Proceedings of the Aquaculture Feed Processing and Nutrition Workshop. Singapore $19-25$ September 1991. Hlm. 42 - 48.

Muslim dan Syaifudin, M. 2012. Budidaya Ikan Gabus (Channa striata). Palembang: UNSRI Press.

Muslim. 2007. Potensi, Peluang dan Tantangan Budidaya Ikan Gabus (Channa striata) di Sumatera Selatan. Prosiding Seminar Nasional Forum Perairan Umum Indonesia IV, Palembang 30 November 2007. Badan Riset Kelautan dan Perikanan. Departemen Kelautan dan Perikanan. ISBN : 978-9791156-10-3.

Narra, M. R., Rajender , K., Reddy R. R., J., Rao, V., \& Begum, G. 2015. The role of vitamin $\mathrm{C}$ as antioxidant in protection of biochemical and haematological tekanans induced by chlorpyrifos in freshwater fish 
Clarias batrachus. Chemosphere, $132,172-178$.

Nasoetion, A.H. dan Barizi. 1983. Metode Statistik untuk Penarikan Kesimpulan. PT. Gramedia. Jakarta : Anggota Ikapi.

Pakaya, D. 2014. Peranan Vitamin C. Jurnal Ilmiah Kedokteran, 1(2). pp: 45-54.

Sudjana. 1996. Metode Statistika. Edisi Keenam. Penerbit Tarsito, Bandung.

Sukmawati, D. 1999. Stres Oksidatif, Antioksidan Vitamin dan Kesehatan. Majalah Kedokteran Indon, 2 (2). pp: 61 69.

Sunarto, Suriansyah, dan Sabariah. 2008. Pengaruh Pemberian Vitamin C Ascorbic Acid Terhadap Kinerja Pertumbuhan dan Respon Imun Ikan Betok Anabas testudineus Bloch. Jurnal Akuakultur Indonesia, 7(2) pp: 151- 157.

Syatriani, S., dan Astrina, A. 2010. Konsumsi Makanan dan Kejadian Anemia pada Siswi Salah Satu SMP di Kota Makassar. Jurnal
Kesehatan Masyarakat Nasional. 4(8). pp: 251-254.

Yulisman, Mirna, F., dan Jubaedah, D. 2012. Peningkatan Pertumbuhan dan Efisiensi Pakan Ikan Gabus (Channa sriata) Melalui Optimasi Kandungan Protein dalam Pakan. Berkala Perikanan Terubuk, 40(2). pp: 4755.

Zhou, Q., Wang, L., Wang, H., Xie, F., \& Wang, T. 2012. Effect of dietary vitamin C on the growth performance and innate immunity of juvenile cobia (Rachycentron canadum). Fish Shellfish Immunol. 32, 969-975.

Zhou, Q., Wang, L., Wang, H., Xie, F., \& Wang, T. 2012. Effect of dietary vitamin C on the growth performance and innate immunity of juvenile cobia (Rachycentron canadum). Fish \& Shellfish Immunology, 32(6), 969-975. 